\title{
Evaluating usability of and satisfaction with two types of dental CAD software
}

\author{
Seong-Min Kim, ${ }^{1,2}$, Wan-Sun Lee ${ }^{2}$, Keunbada Son ${ }^{2,3}$, Kyu-Bok Lee ${ }^{1,2 *}$ \\ 'Department of Prosthodontics, School of Dentistry, Kyungpook National University, Daegu, Republic of Korea \\ ${ }^{2}$ Advanced Dental Device Development Institute, Kyungpook National University, Daegu, Republic of Korea \\ ${ }^{3}$ Department of Dental Science, Graduate School, Kyungpook National University, Daegu, Republic of Korea
}

Purpose: This study evaluated the usability of and satisfaction with two types of computer-aided design (CAD) software among users who had experience with dental implant CAD software and those who did not. Materials and Methods: Dental technicians ( $\mathrm{n}$ $=20)$ who had previous experience with dental implant CAD Software and students from the College of Dentistry $(n=12)$ who had never designed implant custom abutments were asked to evaluate two types of CAD Software, Exocad and Deltanine. In addition, the participants were asked to fill out a structured questionnaire (Section 1: Entering basic information and retrieving files; Section 2: Setting conditions before abutment design; Section 3: Setting abutment design; and Section 4: Overall satisfaction). For the statistical analysis of the collected data, Mann-Whitney $U$ test was used $(\alpha=.05)$. Results: The ease of design and satisfaction with the implant CAD Software, evaluated with respect to 21 statements divided into four Stages, were significantly higher for Exocad in both groups for Secion 1. For Sections 2 and 3, participants with experience evaluated Deltanine to be significantly better. For Section 4, both groups evaluated Exocad Software to be better. Conclusion: Overall, the Exocad Software was evaluated as having better usability and offering greater satisfaction. However, in terms of performance in the core of the design process, i.e. Sections 2 and 3, Deltanine was rated higher by the experienced users. Thus, if the user interface design parts are supplemented, Deltanine CAD Software could be put to a wider use in clinics. (J Dent Rehabil Appl Sci 2019;35(1):11-9)

Key words: CAD software; usability; satisfaction; customized abutment; design

\section{Introduction}

The impact of dental computer-aided design/computer-aided manufacturing (CAD/CAM) systems is gradually increasing in the field of dental prostheses, such as crown, bridge, inlay, and implant patient-customized abutment. ${ }^{1-5}$ The use of dental CAD/CAM systems results in a reduction in costs and shortening of production time, and also facilitates the use of new prosthetic manufacturing methods with new

*Correspondence to: Kyu-Bok Lee

Professor, Department of Prosthodontics, School of Dentistry, Advanced Dental Device Development Institute, Kyungpook National University,

2177 Dalgubul-daero, Jung-gu, Daegu, 41940, Republic of Korea

Tel: +82-53-600-7674, Fax: +82-53-427-0778, E-mail: kblee@knu.ac.kr

Received: October 19, 2018/Last Revision: December 13, 2018/Accepted:

December 18, 2018 prosthetic materials (e.g., zirconia) as opposed to the traditional methods, including impression-taking and wax mold production, casting, and grinding. ${ }^{6-10}$

Dental CAD/CAM consists of three stages. First, the stage of information compiling, where intraoral geometric forms are converted to digital in a laboratory or using an oral scanner; second, the processing stage where the digitized information is processed using CAD Software; and the final stage of production where prosthesis is produced using milling or

Copyright@ 2019 The Korean Academy of Stomatognathic Function and Occlusion. (c) It is identical to Creative Commons Non-Commercial License. 
3D printing. ${ }^{7}$ These individual processes act in concert to produce an accurate and highly comprehensive dental prosthesis. An error that occurs in any of these three processes may bring about the distortion of the prosthesis and, as a result, shorten its lifespan. Thus, various studies have been conducted on scanning process, CAD Software, and milling machine or $3 \mathrm{D}$ printing.

Out of the three stages, the CAD process is the step where dental prosthesis is digitally produced with CAD software, utilizing the scan data collected during the initial stage of information collection. ${ }^{11}$ Currently, in the field of digital dentistry, a variety of CAD software packages are used including 3Shape Dental System (3shape A/S, Copenhagen, Denmark) and Exocad (Exocad GmbH, Darmstadt, Germany).

To achieve excellence in dental prosthesis, the skill of the dental technicians who utilize the CAD Software is essential. In addition, the dental technicians who mastered the use of CAD Software would be the ideal reviewers to understand and evaluate the strengths and weaknesses of the relevant CAD Software. Thus, it is absolutely necessary to investigate and evaluate the usability of and satisfaction with existing CAD programs among skilled dental technicians for the development of better, more advanced CAD software packages.

Despite the importance of this problem, few studies have been conducted on the usability and satisfaction of dental technicians with designing dental prosthesis using CAD Software. This study evaluated the usability and satisfaction with CAD Software by dental technicians in active workforce. A software package already widely used in clinics and newly developed CAD Software were compared. In addition, this study investigated the beginners' experience with CAD Software and compared the satisfaction of experts and beginners with two different software packages.

\section{Materials and Methods}

\section{Research Methods}

Dental technicians in active workforce with expe- rience in operating dental CAD/CAM and college students of dentistry, who were first-time users, were asked to design patient-customized implant abutments using two types of CAD Software. In addition, they were asked to respond to survey questions that tested their understanding, including entering basic information and retrieving files, setting conditions before abutment design, setting abutment design, as well as assessing their overall satisfaction through a structured questionnaire with the selfadministration method (Table 1,2). The participants of this study were 20 dental technicians active in Daegu and 12 junior and senior students in Kyungpook National University School of Dentistry. The study was conducted from May 8 through June 11, 2017. The dental technicians who had experience in using CAD Software were designated as experienced personnel, while the subjects without a previous experience were designated as inexperienced users. The CAD software programs for implant abutment design that were evaluated include Exocad (Exocad GmbH, Darmstadt, Germany) and Deltanine (Daesung, Seoul, Korea) (Fig. 1).

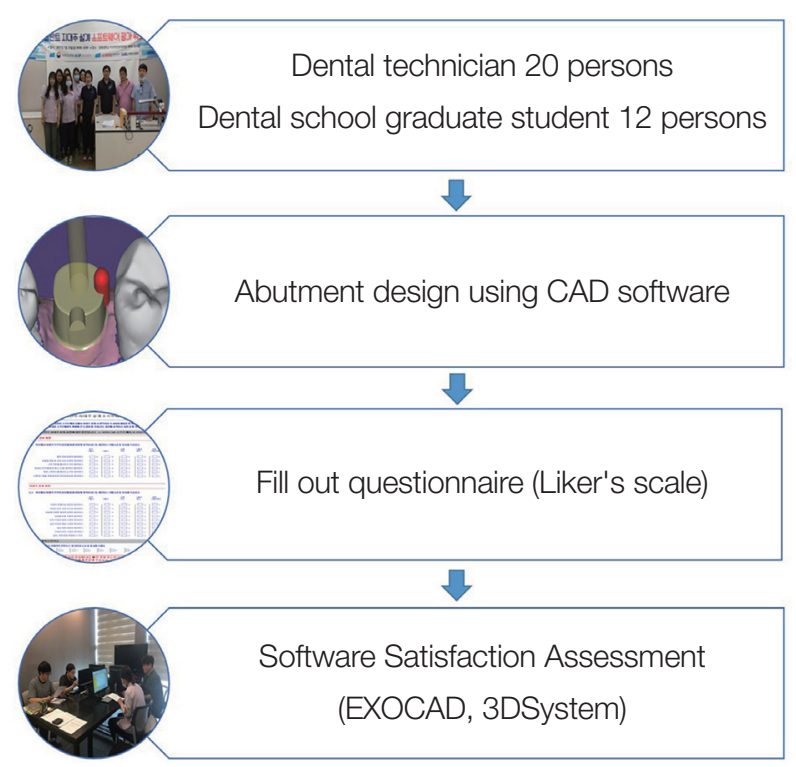

Fig. 1. The flowchart of this study. 
Table 1. Statements in the questionnaire in Sections 1 and 2

\begin{tabular}{|c|c|c|c|}
\hline Classification & $\begin{array}{c}\text { No. of } \\
\text { a large section }\end{array}$ & $\begin{array}{c}\text { No. of } \\
\text { a small section }\end{array}$ & Statements \\
\hline $\begin{array}{l}\text { 1. Entering basic } \\
\text { information }\end{array}$ & 1 & $1-1$ & $\begin{array}{l}\text { It is easy to use user interface design such as screen composition } \\
\text { and menu. }\end{array}$ \\
\hline and retrieving files & & $1-2$ & The user interface design of the Software is sophisticated. \\
\hline & & $1-3$ & It is easy to enter patient information. \\
\hline & & $1-4$ & It is easy to retrieve data and designate files. \\
\hline $\begin{array}{l}\text { 2. Setting conditions } \\
\text { before abutment }\end{array}$ & 2 & $2-1$ & $\begin{array}{l}\text { It is easy to use the user interface design in setting conditions } \\
\text { before design. }\end{array}$ \\
\hline \multirow[t]{7}{*}{ design } & & $2-2$ & $\begin{array}{l}\text { It is easy to manipulate images (To enlarge, reduce, move, and } \\
\text { rotate). }\end{array}$ \\
\hline & & $2-3$ & It is easy to adjust the occlusal surface and in the buccal direction. \\
\hline & & $2-4$ & It is easy to select the scan body (Locator). \\
\hline & & $2-5$ & $\begin{array}{l}\text { The process of overlapping the scan body (Image and library) is } \\
\text { convenient. }\end{array}$ \\
\hline & & $2-6$ & It is easy to manipulate it for the setting the margin line. \\
\hline & & $2-7$ & It is easy to modify the margin line. \\
\hline & & $2-8$ & The default setting is reasonably set. \\
\hline
\end{tabular}

Table 2. Statements in the questionnaire in Sections 3 and 4

\begin{tabular}{|c|c|c|c|}
\hline Classification & $\begin{array}{l}\text { No. of } \\
\text { a large section }\end{array}$ & $\begin{array}{c}\text { No. of } \\
\text { a small section }\end{array}$ & Statements \\
\hline \multirow{8}{*}{$\begin{array}{l}\text { 3. Setting abutment } \\
\text { design }\end{array}$} & \multirow[t]{8}{*}{3} & $3-1$ & It is easy to use user interface design in the design setting. \\
\hline & & $3-2$ & It is easy to adjust the size and shape of the crown. \\
\hline & & $3-3$ & It is easy to adjust the size and shape of the lower abutment. \\
\hline & & $3-4$ & It is easy to adjust the size and shape of the upper abutment. \\
\hline & & $3-5$ & It has various functions of setting the upper and lower abutments. \\
\hline & & $3-6$ & The finally designed abutment is designed to the desired shape. \\
\hline & & $3-7$ & The shape of the crown in the library is satisfactory. \\
\hline & & $3-8$ & The default setting is reasonably set. \\
\hline 4. Overall satisfaction & 4 & $4-1$ & Overall satisfied \\
\hline
\end{tabular}

\section{Developing questionnaire statements}

The dental technicians filling out the questionnaire were asked to state their position, gender, age, clinical experience, the experience in using CAD software, and the name of the CAD software they used. Likewise, the college students of dentistry filling out the questionnaire were asked to state their gender and age.
"Entering basic information and retrieving files" section was composed of four questions, including three statements about the ease of entering basic information and retrieving files in the CAD Software program, and one question about satisfaction. Each question was interpreted on a five-point Likert scale: five points for "Strongly agree," four for "Agree," three for "Neutral," two for "Disagree," and one for "Strongly disagree." The higher score corresponded to better usability and higher satisfaction. 
"Setting conditions before abutment design" section was composed of eight questions, including seven statements about the usability of setting conditions before patient-customized implant abutment design and one question about satisfaction. The questions were focused on evaluating whether or not various conditions facilitated patient-customized abutment design. The same five-point Likert scale was used here as described in the previous section.

"Setting abutment design" section was composed of eight questions, including four statements about the usability of implant patient-customized setting abutment design and four statements about satisfaction. The same five-point Likert scale was used here as described in the previous section.

The overall satisfaction was assigned numeric ratings from 1 through 10 and recorded after the completion of the survey for all statements.

\section{Statistical analysis}

The distribution of the survey scores did not follow the normal distribution pattern when ShapiroWilk's test was used $(P<0.05)$. Thus, satisfaction with each statement in the two groups based on the CAD Software was verified by Mann-Whitney U test $(\mathrm{a}=0.05)$.

A

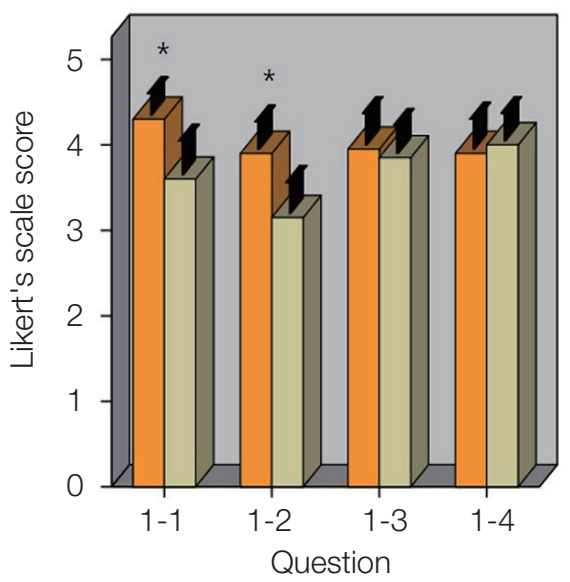

\section{Results}

This survey was evaluating the design usability and satisfaction with the implant CAD Software; the survey consisted of four Sections (21 statements). The results of this survey are as follows:

The experienced users graded the statements " $I t$ is easy to use UI design such as screen composition and menu" and "The UI design of the Software is sophisticated" significantly higher, while the inexperienced users graded the statement "It is easy to use UI design such as screen composition and menu" significantly higher. At this section, the satisfaction was significantly higher with Exocad in both groups (Fig. 2).

The experienced users graded the statement "It is easy to modify the margin" significantly higher, and there were no significant differences in all other statements between the two groups. At this section, the experienced users evaluated Deltanine more highly, while the inexperienced users evaluated Exocad more highly (Fig. 3).

The experienced users graded the statements "It is easy to adjust the upper abutment to the desired size and shape" and "It has diverse functions by which the upper and lower abutments are set" significantly higher, and there were no significant differences in all other statements between the two groups. However,

Fig. 2. Scores of experienced (A) and inexperienced users (B) in Section 1.

* Significantly different $(P<0.05)$.

B

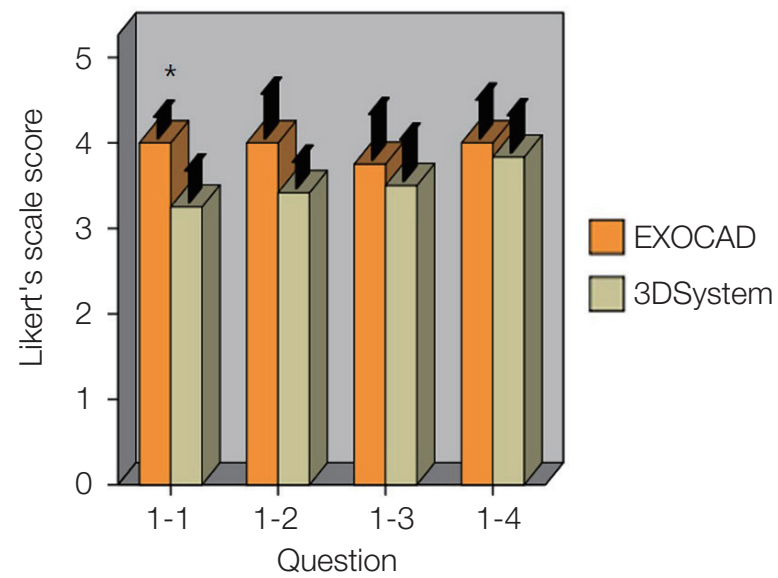


A

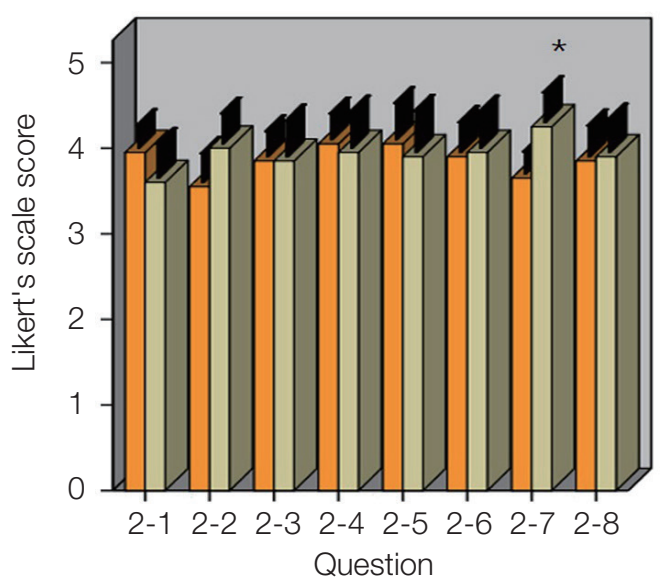

B

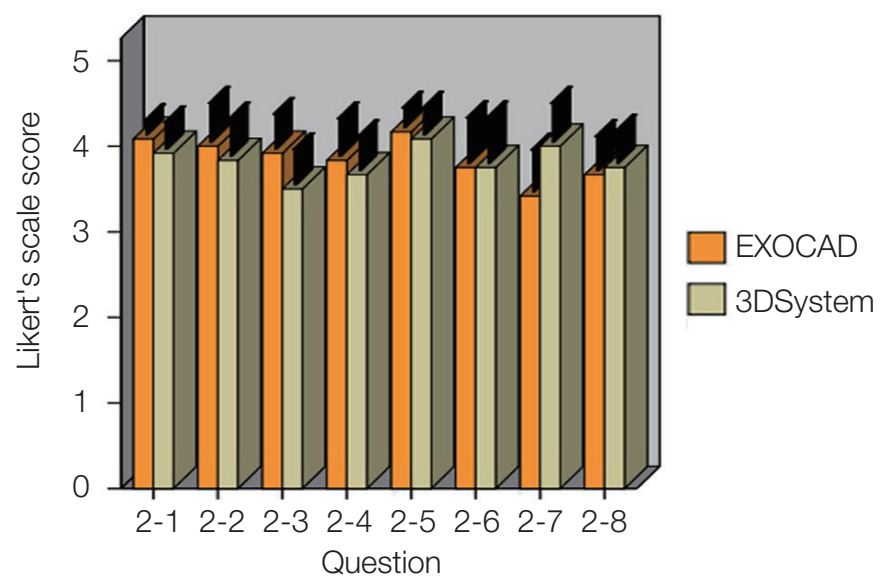

Fig. 3. Scores of experienced (A) and inexperienced users (B) in Section 2.

* Significantly different $(P<0.05)$.

A

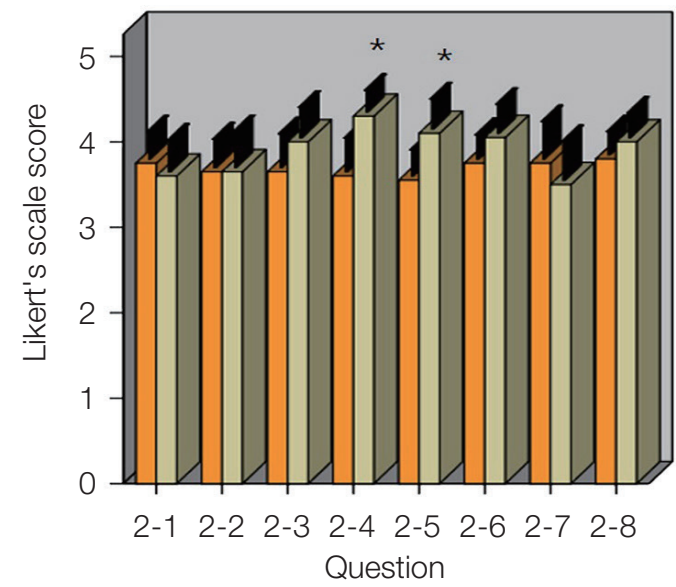

B

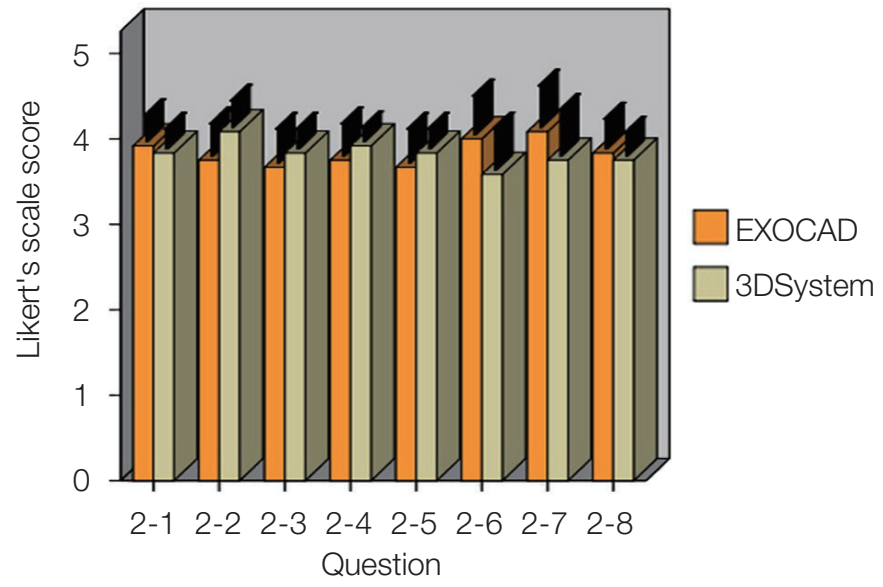

Fig. 4. Scores of experienced (A) and inexperienced users (B) in Section 3.

* Significantly different $(P<0.05)$.

A

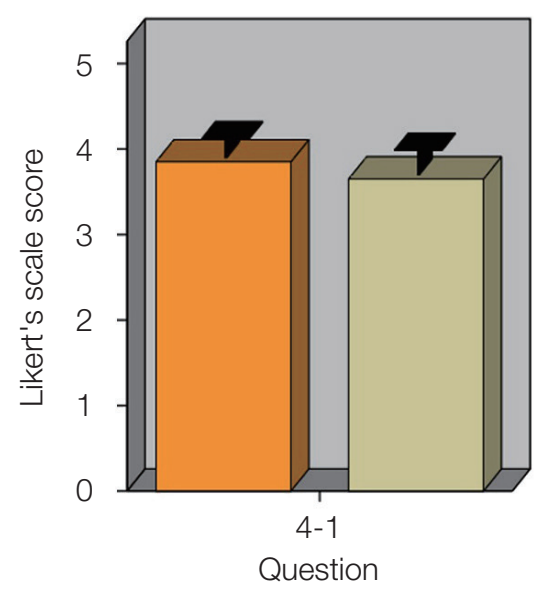

B

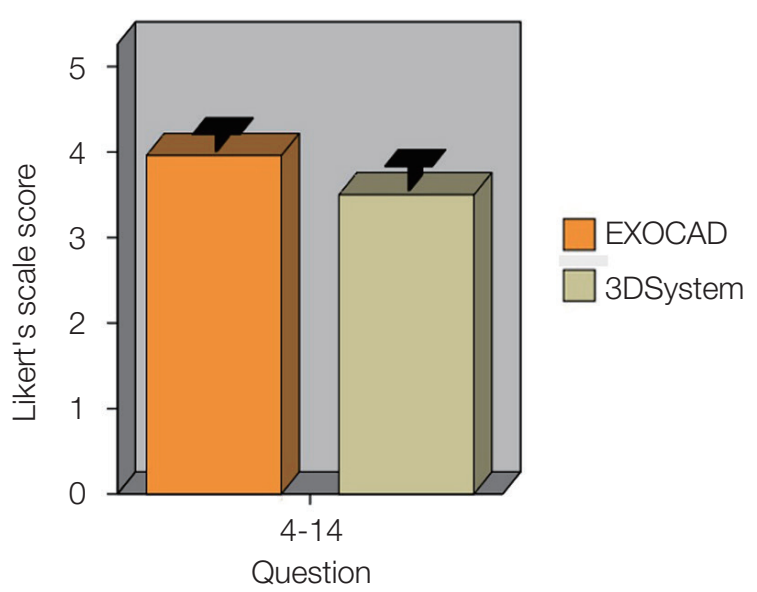

Fig. 5. Scores of experienced (A) and inexperienced users (B) in Section 4. 
in this section, the experienced users evaluated Deltanine significantly more highly (Fig. 4).

There were no statistically significant differences between the two groups (experienced and inexperienced users), but satisfaction with Exocad was higher (Fig. 5).

\section{Discussion}

This study conducted a survey of user interface, usability for patient-customized abutment design, and satisfaction after production for two types of CAD software, Exocad and Deltanine. The results were evaluated and compared for two user groups. To conduct a comparative study of the two types of CAD Software, the survey of satisfaction was conducted in the same location with the same computer. A comparative study is a method that evaluates the strengths and weaknesses of one feature as compared to two or more with similar properties, and can reveal the underlying trends most efficiently. The characteristics of each program can be better understood by comparing and evaluating two types of software side-by-side; some trends would be difficult to identify if only one program were evaluated. In addition, this type of study can directly compare relative strengths and weaknesses between the two programs. ${ }^{12}$

In the evaluation of the survey statements among the experienced users, in the section on "entering basic information and retrieving files", the satisfaction with Exocad was significantly higher than with Deltanine in the "It is easy to use UI design such as screen composition and menu" and "The UI design of the Software is sophisticated" statements. This can be explained by relatively longer availability of Exocad in clinics and program upgrades through users' feedback, that resulted in better outcomes in terms of usability and UI design. In other words, given that Deltanine is restricted to South Korea, there is a limited number of users and they felt relatively less familiar with the Deltanine as compared to Exocad.

In the evaluation of the survey statements among the inexperienced users, in the section on "entering basic information and retrieving files," the satisfac- tion with Exocad was significantly higher than with Deltanine in the "It is easy to use UI design such as screen composition and menu." An inconvenient feature of Exocad is the requirement to designate each file when retrieving scan data for the upper jaw and lower jaw, while in Deltanine, one can retrieve the folder that contains the scan data at once. So, it was initially expected that the result would be opposite in the survey with the inexperienced users, unacquainted with the Exocad program. And yet, it appears that big emoticons on the Exocad main page and more intuitive screen design produced as a result of extensive user feedback are also attractive for inexperienced users. Moreover, these features of Exocad also appeared important for the inexperienced users' overall satisfaction with the program, as their overall satisfaction was significantly higher with Exocad than with Deltanine.

In 2014, Hyun and Park noted that, in choosing a particular product, desirability is an important factor for inexperienced users, and reliability is an important factor for the experienced users. ${ }^{13}$ The desirability of CAD Software may be largely influenced by the design elements, since it is difficult to appreciate its functional properties and this reason alone could determine the overall satisfaction.

For the experienced users, the sections of "setting conditions before abutment design" and "setting abutment design," Deltanine had significantly higher scores than Exocad for the statements, "It is easy to modify the margin", "It is easy to adjust the upper abutment to the desired size and shape", and "It has diverse functions by which the upper and lower abutment can be set". This result is the opposite to the survey of satisfaction with the statement "entering basic information and retrieving files" that favored Exocad. In retrospect, the previous result was caused by the positive effect of familiarity with the software, while here the familiarity allowed the experienced users to spot the weaknesses easier. It appears that a relative newcomer, Deltanine Software, attempted to improve the convenience for some of the functions and this was noted here when compared to Exocad.

There was no significant difference in data for the statements "setting conditions before abutment 
design" and "setting abutment design" among the inexperienced users with respect to both programs. Abutment design requires substantial expertise and skills, so it might be too difficult for the inexperienced users to compare the differences and strengths and weaknesses.

A limitation of this study is the small number of subjects. It was difficult to recruit subjects in the experienced user group since they should be dental technicians who had experience with operating CAD software. It would be necessary to recruit a greater number of participants from wider geographical areas (not limited to Daegu) in order to increase the reliability and feasibility of this research in the future. In addition, this study was limited to comparing only two types of CAD software, Exocad and Deltanine. Including other types of CAD programs and evaluating satisfaction with each of them would better contribute to the development of the comprehensive CAD Software.

\section{Conclusions}

This study arrived at the following conclusions:

1. More users preferred UI design of Exocad than that of Deltanine.

2. Generally, the Exocad Software was evaluated as having better usability and offering greater satisfaction.

3. Deltanine CAD Software, also, is satisfactory and it can be widely used in clinics.

4. Deltanine CAD Software includes straightforward steps to modify the margin and to adjust the size and shape of the upper abutment. It has diverse functions whereby the upper/lower abutment can be set, which can provide additional help to the users who are familiar with any CAD Software.

\section{Acknowledgements}

This work was supported by Institute for Information \& Communications Technology Promotion (IITP) grant funded by the Korea government (MSIP) (B0101-17-1081, Development of ICT based soft- ware platform and service technologies for medical $3 \mathrm{D}$ printing applications) and Industrial Strategic Technology Development Program (10062635, New hybrid milling machine with a resolution of less than $10 \mu \mathrm{m}$ development, using open CAD/CAM S/W integrated platforms for one day prosthetic treatment of 3D smart medical care system) funded By the Ministry of Trade, Industry \& Energy (MOTIE, Korea)

\section{ORCID}

Seong-Min Kim https://orcid.org/0000-0002-6403-3122

Wan-Sun Lee https://orcid.org/0000-0002-4410-5854

Keunbada Son https://orcid.org/0000-0002-3177-8005

Kyu-Bok Lee https://orcid.org/0000-0002-1838-7229

\section{References}

1. Tapie L, Chiche N, Boitelle P, Morenton P, Attal JP, Schmitt N, Vennat E. Adaptation measurement of CAD/CAM dental crowns with X-ray micro-CT: metrological chain standardization and 3D gap size distribution. Advances Mater Sci Eng 2016;4:13.

2. Fasbinder DJ. Computerized technology for restorative dentistry. Am J Dent 2013;26:115-20.

3. van Noort R. The future of dental devices is digital. Dent Mater 2012;28:3-12.

4. Miyazaki T, Hotta Y, Kunii J, Kuriyama S, Tamaki Y. A review of dental CAD/CAM: current status and future perspectives from 20 years of experience. Dent Mater J 2009;28:44-56.

5. Beuer F, Schweiger J, Edelhoff D. Digital dentistry: an overview of recent developments for CAD/CAM generated restorations. Br Dent J 2008;204:505-11.

6. Park JH, Kim JE, Shim JS. Digital workflow for a dental prosthesis that considers lateral mandibular relation. J Prosthet Dent 2017;117:340-44.

7. Davidowitz G, Kotick PG. The use of CAD/CAM in dentistry. Dent Clin North Am 2011;55:559-70.

8. Koch GK, Gallucci GO, Lee SJ. Accuracy in the digital workflow: from data acquisition to the digitally milled cast. J Prosthet Dent 2016;115:749-54.

9. Christensen GJ. Impressions are changing: decid- 
ing on conventional, digital or digital plus in-office milling. J Am Dent Assoc 2009;140:1301-4.

10. Lins L, Bemfica V, Queiroz C, Canabarro A. In vitro evaluation of the internal and marginal misfit of CAD/CAM zirconia copings. J Prosthet Dent 2015;113:205-11.

11. Son KBD, Lee WS, Lee KB. Effect of repeated learning for two dental CAD Software programs. J
Dent Rehabil Appl Sci 2017;33:88-96.

12. Lijphart A. II. The comparable-cases strategy in comparative research. Comp Polit Stud 1975;8:15877.

13. Hyun SE, Park SY. Brand processing difference for experience and no-experience: cultural implications. J Culture Industry 2014;14:159-68. 


\section{두 종류 치과 임플란트 캐드 소프트웨어의 사용자 편의성 및 만족도 비교}

\section{김성민, 이완선, 손큰바다, 이규복*}

${ }^{1}$ 경북대학교 치과대학 치과보철학교실

${ }^{2}$ 경북대학교 첨단치과의료기기개발연구소

${ }^{3}$ 경북대학교 대학원 치의과학과

목적: 치과 임플란트 캐드 소프트웨어를 사용해 본 경험자와 무경험자에 의한 두 종류 캐드 소프트웨어의 사용자 편의성 및 만족도를 평가하는 것이다.

연구 재료 및 방법: 치과 임플란트 캐드 소프트웨어에 경험이 있는 20 명의 치기공사와 캐드 소프트웨어를 사용해보지 않 은 12 명의 경북대학교 치과대학 학생에게 두 종류의 캐드 소프트웨어(ExoCad, Deltanine)를 이용하여 임플란트 맞춤 지 대주(implant custom abutment)를 디자인하도록 하였다. 그리고 구조화된 설문지(1단계: 기본 정보 및 파일 불러오기, 2 단계: 지대주 디자인 전 조건 설정, 3 단계: 지대주 디자인 설정, 4단계: 전체적인 만족도)를 작성하도록 하였다. 수집된 자 료의 통계분석은 Mann-Whitney U test를 사용하였다 $(\alpha=.05)$.

결과: 4단계로 나누어 진 21개 문항에 대해 평가된 치과 임플란트 캐드 소프트웨어의 디자인 편의성과 만족도는 1단계 의 두 문항에서 모두 Exocad 소프트웨어에서 유의하게 높았습니다. 2단계 및 3단계의 경우 경험이 있는 참가자는 Deltanine 소프트웨어가 훨씬 뛰어나다고 평가했습니다. 4단계에서는 두 문항 모두 Exocad 소프트웨어에서 높은 평가를 받 았습니다.

결론: 2 종류 치과 임플란트 캐드 소프트웨어의 편의성 및 만족도 조사에서 Exocad 소프트웨어가 전체적으로 높은 평가 를 받았다. 하지만 디자인 과정 중 핵심인 2, 3단계에서 유경험자는 Deltanine 소프트웨어를 높게 평가하였다. 따라서 그 외 부분을 보강하면 Deltanine 소프트웨어는 임상에서 널리 사용될 수 있을 것이다.

(구강회복응용과학지 2019;35(1):11-9)

주요어: 캐드 소프트웨어; 사용성; 만족도; 커스텀 어버트먼트; 디자인

*교신저자: 이규복

(41940)대구광역시 중구 달구벌대로 2177 경북대학교 치과대학 보철학교실, 경북대학교 첨단치과의료기기개발연구소(A3DI)

Tel: +82-53-600-7674 | Fax: +82-53-427-0778 || E-mail: kblee@knu.ac. kr

접수일: 2018년 10월 19일 | 수정일: 2018년 12월 13일 | 채택일: 2018년 12월 18일 